\section{Growth and Appearance Quality of Four Microgreen Species under Light- emitting Diode Lights with Different Spectral Combinations}

\author{
Qinglu Ying, Yun Kong, and Youbin Zheng \\ School of Environmental Sciences, University of Guelph, 50 Stone Road East, \\ Guelph, Ontario N1G 2W1, Canada
}

Additional index words. biomass, Brassica juncea, Brassica napus, Brassica oleracea var. capitata f. rubra, controlled environment, cotyledon area, Eruca sativa, far-red light, fluorescent light, green light, hue angle, plant height

\begin{abstract}
To investigate plant growth and quality responses to different light spectral combinations, cabbage (Brassica oleracea L. var. capitata f. rubra), kale (Brassica napus L. 'Red Russian'), arugula (Eruca sativa L.), and mustard (Brassica juncea L. 'Ruby steak') microgreens were grown in a controlled environment using sole-source light with six different spectra: 1) FL: cool white fluorescent light; 2) BR: $15 \%$ blue and $85 \%$ red light-emitting diode (LED); 3) BRFR $\mathrm{L}_{\mathrm{L}}: 15 \%$ blue, $85 \% \mathrm{red}$, and $15.5 \mu \mathrm{mol} \cdot \mathrm{m}^{-2} \cdot \mathrm{s}^{-1}$ farred (FR) LED; 4) BRFR $_{\mathrm{H}}: 15 \%$ blue, $85 \%$ red, and $155 \mu \mathrm{mol} \cdot \mathrm{m}^{-2} \cdot \mathrm{s}^{-1}$ FR LED; 5) $\mathrm{BG}_{\mathrm{L}}$ R: $9 \%$ blue, $6 \%$ green, and $85 \%$ red $L E D$; and 6$) \mathrm{BG}_{\mathrm{H}} \mathrm{R}$ : $5 \%$ blue, $10 \%$ green, and $85 \%$ red LED. For all the light treatments, the total photosynthetic photon flux density (PPFD) was set at $\approx 330 \mu \mathrm{mol} \cdot \mathrm{m}^{-2} \cdot \mathrm{s}^{-1}$ under a 17 -hour photoperiod, and the air temperature was $\approx 21{ }^{\circ} \mathrm{C}$ with $73 \%$ relative humidity (RH). At harvest, BR vs. FL increased plant height for all the tested species except arugula, and enlarged cotyledon area for kale and arugula. Adding high-intensity FR light to blue and red light (i.e., $B R F R_{H}$ ) further increased plant height for all species, and cotyledon area for mustard, but it did not affect the fresh or dry biomass for any species. Also, BRFR H $_{H}$ vs. BR increased cotyledon greenness for green-leafed species (i.e., arugula, cabbage, and kale), and reduced cotyledon redness for red-leafed mustard. However, $B G_{L} R, B G_{H} R$, and $B R F R_{L}$, compared with $B R$, did not affect plant height, cotyledon area, or fresh or dry biomass. These results suggest that the combination of $15 \%$ blue and $85 \%$ red LED light can potentially replace FL as the sole light source for indoor production of the tested microgreen species. Combining high-intensity FR light, rather than low-level $(\mathbf{S 1 0} \%)$ green light, with blue and red light could be taken into consideration for the optimization of LED light spectral quality in microgreen production under environmental conditions similar to this experiment.
\end{abstract}

Microgreens are gaining increasing attention and consumption in recent years because of their various colors, unique flavors and textures, and higher nutrition levels compared with their mature counterparts (Treadwell et al., 2016; Xiao et al., 2012). Typically, microgreens are harvested with two cotyledons fully expanded, and right before or after the first true leaf starts to

Received for publication 11 Feb. 2020. Accepted for publication 16 Apr. 2020.

Published online 12 August 2020.

We thank the Natural Sciences and Engineering Research Council of Canada and Greenbelt Microgreens Ltd. for their financial support. We also thank Heliospectra AB (Gothenburg, Sweden) for providing light-emitting diode technologies for this study. Thanks to Dave Llewellyn for his excellent technical support and informative discussion during the trials.

Y.Z. is the corresponding author. E-mail: yzheng@ uoguelph.ca.

This is an open access article distributed under the CC BY-NC-ND license (https://creativecommons. org/licenses/by-nc-nd/4.0/). emerge. Within 80 to 100 plant species that are currently cultivated as microgreens, the most commonly cultivated species are from the Brassicaceae family, including, arugula, cabbage, kale, and mustard (Björkman et al., 2011).

Microgreens are increasingly grown in indoor production facilities with electrical lighting as the sole light source. Fluorescent lights (FLs), especially cool white FLs with enhanced blue and red spectra, were traditionally used for indoor production (Darko et al., 2014; Massa et al., 2006). Recently, LED lights have been developed as a new electrical light source in crop production, and LED light has many advantages over traditional lights (e.g., FLs) (Morrow, 2008). Among the advantages, the adjustable light spectral composition in LED lights enables researchers and growers to manipulate plant morphology and physiology based on production purposes (Davis and Burns, 2016).

LED light with blue light (B) and red light (R) combination (BR) has been popularly used for horticultural crop production in controlled environments (Goto, 2012). BR (containing $5 \%$ to $15 \% \mathrm{~B}$ ) at a $P P F D$ of $\approx 300$ to $400 \mu \mathrm{mol} \cdot \mathrm{m}^{-2} \cdot \mathrm{s}^{-1}$ and a photoperiod of $\approx 16 \mathrm{~h}$ appears to be the optimal light environment for indoor production of microgreens based on crop yield and appearance quality (Jones-Baumgardt et al., 2019; Ying et al., 2020). Also, plants grown under BR vs. FL are generally better in terms of yield and quality. For example, BR, compared with FL with the $P P F D$ ranging from 70 to 250 $\mu \mathrm{mol} \cdot \mathrm{m}^{-2} \cdot \mathrm{s}^{-1}$, increases leaf area of chili pepper (Capsicum annuum) and hybrid moth orchid (Phaelenopsis $\times$ Doritis); fresh weight (FW) and dry weight (DW) of chili pepper, lettuce (Lactuca sativa L.), and hybrid moth orchid; and FW of sprouting broccoli (Brassica oleracea) (Gangadhar et al., 2012; Johkan et al., 2010; Kopsell et al., 2014; Lin et al., 2013; Shin et al., 2008). However, there is a lack of study comparing the effects of $\mathrm{BR}$ relative to $\mathrm{FL}$ under a higher PPFD (e.g., $300-400 \mu \mathrm{mol} \cdot \mathrm{m}^{-2} \cdot \mathrm{s}^{-1}$ ) on microgreen species.

Promoted plant growth has been found when adding FR to BR by eliciting shadeavoidance responses through phytochromes (Park and Runkle, 2017). Under a background lighting with BR $(20 \% \mathrm{~B}$ and $80 \%$ $\mathrm{R} ; \mathrm{B}_{20} \mathrm{R}_{80}$ ) at a PPFD of $130 \mu \mathrm{mol} \cdot \mathrm{m}^{-2} \cdot \mathrm{s}^{-1}$, adding FR with increased levels from $\approx 12$ to $149 \mu \mathrm{mol} \cdot \mathrm{m}^{-2} \cdot \mathrm{s}^{-1}$ (i.e., R:FR ratio decreased from 8.6 to 0.7 ) increases the aboveground FW and DW, and leaf area of lettuce accordingly (Lee et al., 2016). When FR (16-64 $\left.\mu \mathrm{mol} \cdot \mathrm{m}^{-2} \cdot \mathrm{s}^{-1}\right)$ is added to $\mathrm{B}_{20} \mathrm{R}_{80}$ (PPFD of $\left.160 \mu \mathrm{mol} \cdot \mathrm{m}^{-2} \cdot \mathrm{s}^{-1}\right)$, total leaf area and shoot DW are increased in geranium (Pelargonium $\times$ hortorum) and snapdragon (Antirrhinum majus) transplants (Park and Runkle 2017). However, little relevant information is available under higher PPFD (e.g., 300-400 $\left.\mu \mathrm{mol} \cdot \mathrm{m}^{-2} \cdot \mathrm{s}^{-1}\right)$ for microgreens, which have a much shorter growth period than lettuce and flower transplants. For microgreens, $\mathrm{B}_{9} \mathrm{R}_{84}$ $\mathrm{FR}_{7}$ (i.e., 9\% B, 84\% R, and 7\% FR), compared with $B_{13} R_{87}$, increases hypocotyl length and FW in mustard (Brassica juncea L.) under a total photon flux of $315 \mu \mathrm{mol} \cdot \mathrm{m}^{-2} \cdot \mathrm{s}^{-1}$ (Gerovac et al., 2016). However, in this study, FR was not added to BR, but partially replaced $\mathrm{R}$ and $\mathrm{B}$ in $\mathrm{BR}$. In this case, the BRFR, compared with the BR, had a lower B percentage $(9.7 \%$ vs. $13 \%)$ in the total $P P F D$, which can also affect microgreen growth (Ying et al., 2020). Therefore, it is difficult to conclude whether the effects are attributed to higher FR or lower B. Furthermore, only low-level FR (i.e., high R:FR ratio of 12:1) was used for the previous microgreen study. If higher-level FR is included in BR (i.e., lower R:FR ratio), it is unknown whether there will be differences in responses of growth and yield of microgreens under a higher PPFD (e.g., $300-400 \mu \mathrm{mol} \cdot \mathrm{m}^{-2} \cdot \mathrm{s}^{-1}$ ) in indoor production.

Partially replacing $\mathrm{B}$ in $\mathrm{BR}$ with green light $(G)$ has also been shown to promote plant growth by inducing shade-avoidance responses through G-B-interaction-inhibited cryptochrome activity (Meng et al., 2019), as well as by the better ability of $\mathrm{G}$ to penetrate 
Table 1. The four experimental microgreen species, seeding density, and the start and end dates of each replicate.

\begin{tabular}{|c|c|c|c|c|c|c|}
\hline $\begin{array}{l}\text { Plant } \\
\text { materials }\end{array}$ & Scientific name & Plant color & $\begin{array}{l}\text { Seeding } \\
\text { density } \\
\left(\mathrm{g} \cdot \mathrm{m}^{-2}\right)\end{array}$ & Seed source & Seeding date & Harvest date \\
\hline Cabbage & $\begin{array}{l}\text { Brassica oleracea L. var. } \\
\quad \text { capitata f. rubra }\end{array}$ & $\begin{array}{l}\text { Purple stem and } \\
\text { leaf margin } \\
\text { with green } \\
\text { leaf }\end{array}$ & 68.6 & $\begin{array}{l}\text { Mumm's Sprouting Seeds, } \\
\text { Parkside, SK, } \\
\text { Canada }\end{array}$ & $\begin{array}{l}\text { Rep. 1: } 6 \text { Dec. } 2016 \\
\text { Rep. 2: } 6 \text { Jan. } 2017 \\
\text { Rep. 3: } 24 \text { Jan. } 2017\end{array}$ & $\begin{array}{l}\text { Rep. 1: } 16 \text { Dec. } 2016 \\
\text { Rep. 2: } 16 \text { Jan. } 2017 \\
\text { Rep. 3: } 4 \text { Feb. } 2017\end{array}$ \\
\hline Kale & $\begin{array}{l}\text { Brassica napus L. } \\
\text { 'Red Russian' }\end{array}$ & $\begin{array}{l}\text { Purple stem with } \\
\text { green leaf }\end{array}$ & 54.9 & $\begin{array}{l}\text { High Mowing } \\
\text { Organic Seeds, } \\
\text { Wolcott, VT }\end{array}$ & $\begin{array}{l}\text { Rep. 1: } 6 \text { Dec. } 2016 \\
\text { Rep. 2: } 6 \text { Jan. } 2017 \\
\text { Rep. 3: } 24 \text { Jan. } 2017\end{array}$ & $\begin{array}{l}\text { Rep. 1: } 17 \text { Dec. } 2016 \\
\text { Rep. 2: } 17 \text { Jan. } 2017 \\
\text { Rep. 3: } 5 \text { Feb. } 2017\end{array}$ \\
\hline Arugula & Eruca sativa L. & Green leaf & 27.4 & $\begin{array}{l}\text { Suba Seeds } \\
\text { Company S.P.A., } \\
\text { Longiano, FC, } \\
\text { Italy }\end{array}$ & $\begin{array}{l}\text { Rep. 1: } 6 \text { Dec. } 2016 \\
\text { Rep. 2: 6 Jan. } 2017 \\
\text { Rep. 3: } 24 \text { Jan. } 2017\end{array}$ & $\begin{array}{l}\text { Rep. 1: } 17 \text { Dec. } 2016 \\
\text { Rep. 2: } 17 \text { Jan. } 2017 \\
\text { Rep. 3: } 5 \text { Feb. } 2016\end{array}$ \\
\hline Mustard & $\begin{array}{l}\text { Brassica juncea } \\
\text { L. 'Ruby Steak' }\end{array}$ & $\begin{array}{l}\text { Purple leaf vein } \\
\text { or whole } \\
\text { leaf }\end{array}$ & 27.4 & $\begin{array}{l}\text { Johnny's Selected } \\
\text { Seeds, Winslow, } \\
\text { ME }\end{array}$ & $\begin{array}{l}\text { Rep. 1: } 6 \text { Dec. } 2016 \\
\text { Rep. 2: } 6 \text { Jan. } 2017 \\
\text { Rep. 3: } 24 \text { Jan. } 2017\end{array}$ & $\begin{array}{l}\text { Rep. 1: } 16 \text { Dec. } 2016 \\
\text { Rep. 2: } 16 \text { Jan. } 2017 \\
\text { Rep. 3: } 4 \text { Feb. } 2017\end{array}$ \\
\hline
\end{tabular}

plants compared with B and R (Sun et al., 1998). At a $P P F D$ of $\approx 173 \mu \mathrm{mol} \cdot \mathrm{m}^{-2} \cdot \mathrm{s}^{-1}$, the shoot $\mathrm{FW}$ of red leaf lettuce under $\mathrm{B}_{10} \mathrm{G}_{10} \mathrm{R}_{80}$ (i.e., $10 \% \mathrm{~B}, 10 \% \mathrm{G}$, and $80 \% \mathrm{R}$ ) is $\approx 61 \%$ higher than those under $\mathrm{B}_{20} \mathrm{R}_{80}$ (Son and $\mathrm{Oh}$, 2015). Also, at a PPFD of $160 \mu \mathrm{mol} \cdot \mathrm{m}^{-2} \cdot \mathrm{s}^{-1}$, $\mathrm{B}_{25} \mathrm{G}_{25} \mathrm{R}_{50}$ vs. $\mathrm{B}_{50} \mathrm{R}_{50}$ increases shoot biomass, plant height, or leaf area in tomato (Solanum lycopersicum), petunia (Petunia $\times$ hybrida), impatiens (Impatiens walleriana), and salvia (Salvia splendens) (Wollaeger and Runkle, 2015). Similarly, at a PPFD of 180 $\mu \mathrm{mol} \cdot \mathrm{m}^{-2} \cdot \mathrm{s}^{-1}, \mathrm{~B}_{22} \mathrm{G}_{11} \mathrm{R}_{67}$ or $\mathrm{B}_{11} \mathrm{G}_{22} \mathrm{R}_{67}$, comparing to $\mathrm{B}_{33}: \mathrm{R}_{67}$, promotes leaf expansion and increases shoot FW in lettuce and kale (Brassica oleracea) (Meng et al., 2019). However, the preceding studies were carried out on plants other than microgreens, and under a PPFD of $<200 \mu \mathrm{mol} \cdot \mathrm{m}^{-2} \cdot \mathrm{s}^{-1}$. For microgreens, $\mathrm{B}_{8} \mathrm{G}_{18} \mathrm{R}_{74}$, comparing to $\mathrm{B}_{13}$ $\mathrm{R}_{87}$, increases hypocotyl length and shoot FW in mustard under $P P F D$ of $315 \mu \mathrm{mol} \cdot \mathrm{m}^{-2} \cdot \mathrm{s}^{-1}$ (Gerovac et al., 2016). However, in this study, both B and R were replaced by G, which can complicate the $\mathrm{G}$ effects interacting with B. Also, only one G level (i.e., G\% > $\mathrm{B} \%$ ) was designed for BGR light, which made it impossible to compare the effects with lower $\mathrm{G}$ level (i.e., $\mathrm{G} \%<\mathrm{B} \%$ ). Furthermore, the comparison between BGR and BRFR effects on microgreens under a higher PPFD (e.g., $300-400 \mu \mathrm{mol} \cdot \mathrm{m}^{-2} \cdot \mathrm{s}^{-1}$ ) needs further study.

Although some previous studies have explored the optimization of LED lighting spectral quality for microgreen production, the optimal "light recipe" seems to vary with lighting intensity, growth stage, and plant species. The objective of this study was to investigate the plant responses to 1) BR vs. FL, 2) adding different levels of FR to BR, and 3) partial replacement of B in BR by different levels of $G$, in terms of growth and quality of four microgreen species under sole-source LED lighting at a PPFD of $\approx 330 \mu \mathrm{mol} \cdot \mathrm{m}^{-2} \cdot \mathrm{s}^{-1}$.

\section{Materials and Methods}

Plant material and growing conditions. The experiment was conducted on four microgreen species (Table 1) in a walk-in growth chamber $(7.3 \times 4.0 \times 2.5 \mathrm{~m}$, model $\mathrm{W}$ IN FLUSH 00VT 34; Foster Refrigerator of Canada, Calgary, Alberta, Canada). There were six compartments within the chamber, separated by an opaque curtain to prevent neighboring effects. Black plastic trays $(54 \times$ $27 \times 4 \mathrm{~cm})$ were filled with an organic growing substrate that consisting of $30 \%$ compost, $30 \%$ peat, $30 \%$ coir, and $10 \%$ perlite $(\mathrm{v} / \mathrm{v})$. Four microgreen species were seeded in the growing substrate (one species per tray) and covered with coconut coir to maintain moisture during germination. Eight trays (two for each species) were placed inside each compartment under different lighting treatments with the same $P P F D$ of $330 \mu \mathrm{mol} \cdot \mathrm{m}^{-2} \cdot \mathrm{s}^{-1}$ and $17-\mathrm{h}$ photoperiod. All plants were top irrigated at least once daily using well water $(\mathrm{pH}=7.5$; electrical conductivity $=0.8 \mathrm{dS} \cdot \mathrm{m}^{-1}$ ) until visible drainage. The air temperature was set at $20{ }^{\circ} \mathrm{C}$ and the relative humidity $(\mathrm{RH})$ at $75 \%$. The measured temperature in the growth chamber was 20.7 $\pm 0.4^{\circ} \mathrm{C}$ and $\mathrm{RH}$ was $72.5 \% \pm 1.8 \%$ throughout the study $(\mathrm{n}=3)$.

Light treatments. Randomized complete block design was used for this experiment, with one factor (light quality) and three replicates over time. Light quality treatments included the following: 1) FL: cool white FL; 2) BR: $15 \% \mathrm{~B}$ and $85 \% \mathrm{R} ; 3) \mathrm{BRFR}_{\mathrm{L}}: 15 \% \mathrm{~B}$ and $85 \% \mathrm{R}$ with additional $15.5 \mu \mathrm{mol} \cdot \mathrm{m}^{-2} \cdot \mathrm{s}^{-1}$ $\mathrm{FR}$; 4) $\mathrm{BRFR}_{\mathrm{H}}: 15 \% \mathrm{~B}$ and $85 \% \mathrm{R}$ with additional $155 \mu \mathrm{mol} \cdot \mathrm{m}^{-2} \cdot \mathrm{s}^{-1} \mathrm{FR}$; 5) $\mathrm{BG}_{\mathrm{L}} \mathrm{R}$ : $9 \% \mathrm{~B}, 6 \% \mathrm{G}$, and $85 \% \mathrm{R}$; 6) $\mathrm{BG}_{\mathrm{H}} \mathrm{R}: 5 \% \mathrm{~B}$, $10 \% \mathrm{G}$, and $85 \% \mathrm{R}$. Sole-source LED lights (Heliospectra LX602C; Heliospectra AB, Gothenburg, Sweden) or cool white linear FLs (F96T12/CW/VHO; Osram Sylvania Ltd., Markham, Ontario, Canada) were used for the preceding treatments. For each replicate, the six light quality treatments were randomly allocated to six compartments. After each replicate, the six light quality treatments were switched to different compartments within the chamber.

Within the treatment area $(54 \times 54 \mathrm{~cm})$, the LED and FL fixtures were placed $75 \mathrm{~cm}$ and $140 \mathrm{~cm}$, respectively, above the plant canopy to achieve the average target $P P F D$ of $330 \mu \mathrm{mol} \cdot \mathrm{m}^{-2} \cdot \mathrm{s}^{-1}$. The light intensity and spectrum of the LED arrays were set up by
Heliospectra System Assistant (Version 1.3.0; Heliospectra AB). To check light uniformity, light intensity and spectrum were measured at 25 spots at the canopy level within the treatment area under each treatment using a Flame-S spectrometer with a $25-\mu \mathrm{m}$ slit, coupled to a $1.89 \mathrm{~m} \times 400 \mu \mathrm{m}$ solarization-resistant fiberoptic patch chord with a CC-3 Cosine Corrector with spectralon diffuser (Ocean Optics, Inc., Dunedin, FL). The spectrometer was calibrated over 350 to $800 \mathrm{~nm}$ before light measurements. Light intensity and spectra were also checked and confirmed at the end of each replicate. The light intensity and spectral distribution under different light treatments are presented in Fig. 1 and Table 2.

Growth and quality measurements. Plants were harvested $11 \mathrm{~d}$ after seeding for cabbage and kale, and $12 \mathrm{~d}$ after seeding for mustard and arugula (Table 1). Before harvest, for each replicate, four plants from each species were sampled randomly from each tray (treatment) to measure the heights using a ruler. At harvest, three subsamples (with a substrate surface area of $76.4 \mathrm{~cm}^{2}$ each including plants and the substrate) of microgreens were randomly sampled from each tray using a cylindrical core sampler. All the microgreens within each core were cut right above the substrate level and collected to determine FW. These plants were then put in paper bags and dried at $65{ }^{\circ} \mathrm{C}$ until they reached a constant weight to determine DW. The fresh and dry biomass $\left(\mathrm{kg} \cdot \mathrm{m}^{-2}\right)$ were estimated based on average FW and DW of collected microgreens as well as surface areas of sampled cores. From the remaining microgreens in each tray, five plants from each species were selected randomly to analyze the cotyledon area and color. The cotyledons were cut off from the stem and scanned to save as color digital images using a scanner (Canoscan F910111; Canon Inc., Tokyo, Japan) with 300 dpi resolution. The cotyledon area, as well as R, G, and B values (i.e., the amount of R, G, and B light emitted from each pixel in the image on a scale of 0 to 255) were obtained from the digital images using ImageJ 1.42 software (National Institutes of Health, Bethesda, MD). Subsequently, hue angle of the cotyledon color 

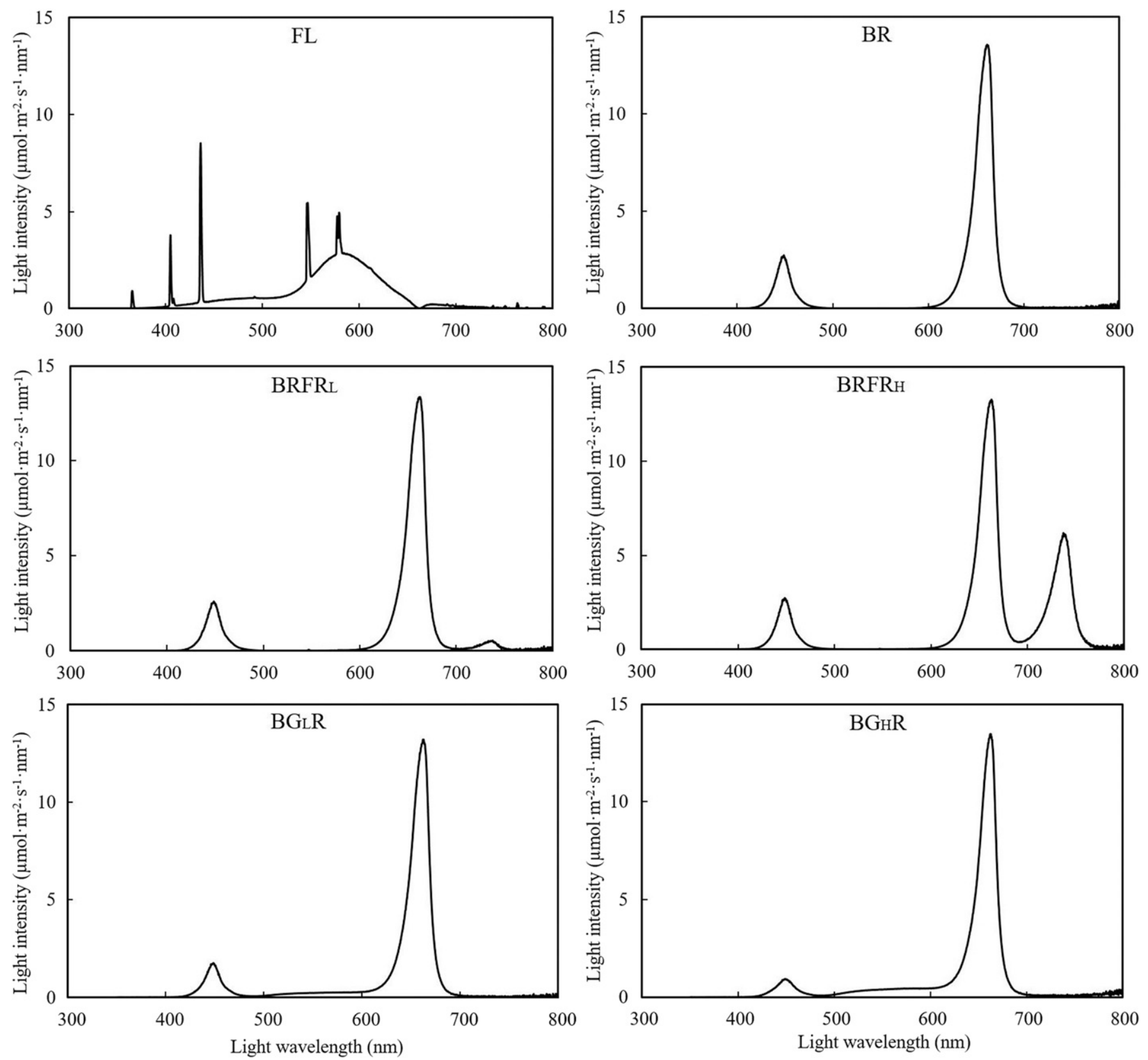

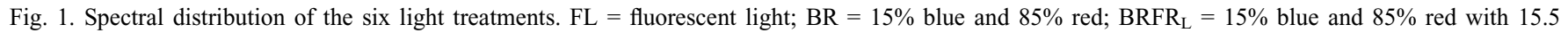
$\mu \mathrm{mol} \cdot \mathrm{m}^{-2} \cdot \mathrm{s}^{-1}$ far-red light; $\mathrm{BRFR} \mathrm{H}_{\mathrm{H}}=15 \%$ blue and $85 \%$ red with additional $155 \mu \mathrm{mol} \cdot \mathrm{m}^{-2} \cdot \mathrm{s}^{-1}$ far-red light; $\mathrm{BG} \mathrm{G}_{\mathrm{L}} \mathrm{R}=9 \%$ blue, $6 \%$ green, and $85 \%$ red; $\mathrm{BG} \mathrm{H}_{\mathrm{H}} \mathrm{R}=$ $5 \%$ blue, $10 \%$ green, and $85 \%$ red. The photosynthetic photon flux density of each lighting treatment is $330 \mu \mathrm{mol} \cdot \mathrm{m}^{-2} \cdot \mathrm{s}^{-1}$.

was calculated from these RGB values using formulas according to Karcher and Richardson (2003). The hue angle of the cotyledon color was calibrated with the actual hue angle of Munsell color chips using Munsell Conversion software for 2018 (Munsell color, 2018).

Statistical analysis. Data were subjected to one-way analysis of variance using the SPSS software (Version 25.0; IBM, New York, NY) and were presented as mean \pm SE. Separation of means was performed using Tukey's honestly significance difference test at the $P \leq 0.05$ level.

\section{Results}

Cotyledon color. Different light treatments affected cotyledon color differently, based on the variation of hue angle in the tested microgreen species (Fig. 2). Under FL, the hue angles of cotyledons were $\approx 55^{\circ}$

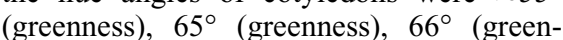
ness), and $349^{\circ}$ (redness) for cabbage, kale, arugula, and mustard, respectively. BR vs. FL reduced the hue angle (i.e., increased redness) of cotyledons for mustard, but showed no differences for the other three species. The cotyledon hue angles of all four tested species were increased under $\mathrm{BRFR}_{\mathrm{H}}$ compared with BR, indicating increased greenness for cabbage, kale, and arugula, and reduced redness for mustard. There was no difference in cotyledon hue angle among $\mathrm{BR}, \mathrm{BG}_{\mathrm{L}} \mathrm{R}$, and $\mathrm{BG}_{\mathrm{H}} \mathrm{R}$ for all the tested species; however, $B_{\mathrm{L}} \mathrm{R}$ reduced cotyledon hue angle from $72^{\circ}$ to $68^{\circ}$ for arugula com- pared with $\mathrm{BRFR}_{\mathrm{L}}$, showing reduced greenness. Also, $\mathrm{BG}_{\mathrm{H}} \mathrm{R}$ reduced this trait from $356^{\circ}$ to $347^{\circ}$ for mustard compared with BRFR $_{\mathrm{H}}$, showing increased redness.

Plant size. The plant heights of all tested microgreen species were affected by different light spectral combinations (Fig. 3). BR, compared with FL, increased plant height by $31 \%, 42 \%$, and $27 \%$ for cabbage, kale, and mustard, respectively. BRFR $_{\mathrm{L}}$ increased plant height of arugula by $36 \%$ compared with BR. BRFR ${ }_{\mathrm{H}}$, compared with BR, increased the plant heights by $36 \%, 31 \%, 68 \%$, and $57 \%$ for cabbage, kale, arugula, and mustard, respectively. There was no difference in this trait among $B R, B_{L} R$, and $\mathrm{BG}_{\mathrm{H}} \mathrm{R}$ for all the tested species. However, plant height was reduced for cabbage, kale, 
Table 2. Mean photon flux density from blue, green, red, far-red, and photosynthetically active radiation (PAR), red:far-red ratios, and phytochrome photostationary state (PPS) of the different light quality treatments.

\begin{tabular}{|c|c|c|c|c|c|c|c|}
\hline \multirow[b]{2}{*}{ Treatments $^{\mathrm{z}}$} & \multicolumn{5}{|c|}{ Light intensity $\left(\mu \mathrm{mol} \cdot \mathrm{m}^{-2} \cdot \mathrm{s}^{-1}\right)$} & \multirow[b]{2}{*}{ Red:far-red ratio } & \multirow[b]{2}{*}{ PPS $^{y}$} \\
\hline & Blue $(400-500 \mathrm{~nm})$ & Green $(500-600 \mathrm{~nm})$ & $\operatorname{Red}(600-700 \mathrm{~nm})$ & Far-red $(700-800 \mathrm{~nm})$ & $P A R$ & & \\
\hline BR & $47.4 \pm 0.6$ & - & $280 \pm 5$ & $3.5 \pm 2.7$ & $329 \pm 5$ & - & $0.88 \pm 0.00$ \\
\hline $\mathrm{BG}_{\mathrm{L}} \mathrm{R}$ & $30.7 \pm 0.1$ & $16.6 \pm 0.6$ & $279 \pm 4$ & - & $326 \pm 4$ & - & $0.88 \pm 0.00$ \\
\hline $\mathrm{BG}_{\mathrm{H}} \mathrm{R}$ & $18.8 \pm 1.2$ & $28.5 \pm 0.8$ & $278 \pm 3$ & - & $325 \pm 4$ & - & $0.88 \pm 0.00$ \\
\hline
\end{tabular}

${ }^{{ }^{\mathrm{B} L}}=$ fluorescent light; $\mathrm{BR}=15 \%$ blue and $85 \%$ red; $\mathrm{BRFR}_{\mathrm{L}}=15 \%$ blue and $85 \%$ red with $15.5 \mu \mathrm{mol} \cdot \mathrm{m}^{-2} \cdot \mathrm{s}^{-1}$ far-red light; $\mathrm{BRFR} \mathrm{H}_{\mathrm{H}}=15 \%$ blue and $85 \%$ red with additional $155 \mu \mathrm{mol} \cdot \mathrm{m}^{-2} \cdot \mathrm{s}^{-1}$ far-red light; $\mathrm{BG}_{\mathrm{L}} \mathrm{R}=9 \%$ blue, $6 \%$ green and $85 \%$ red; $\mathrm{BG}_{\mathrm{H}} \mathrm{R}=5 \%$ blue, $10 \%$ green and $85 \%$ red.

${ }^{\mathrm{y}} \mathrm{PPS}$ is calculated according Sager et al. (1988).

${ }^{\mathrm{x}}$ Data are means $\pm \operatorname{SE}(\mathrm{n}=3)$.

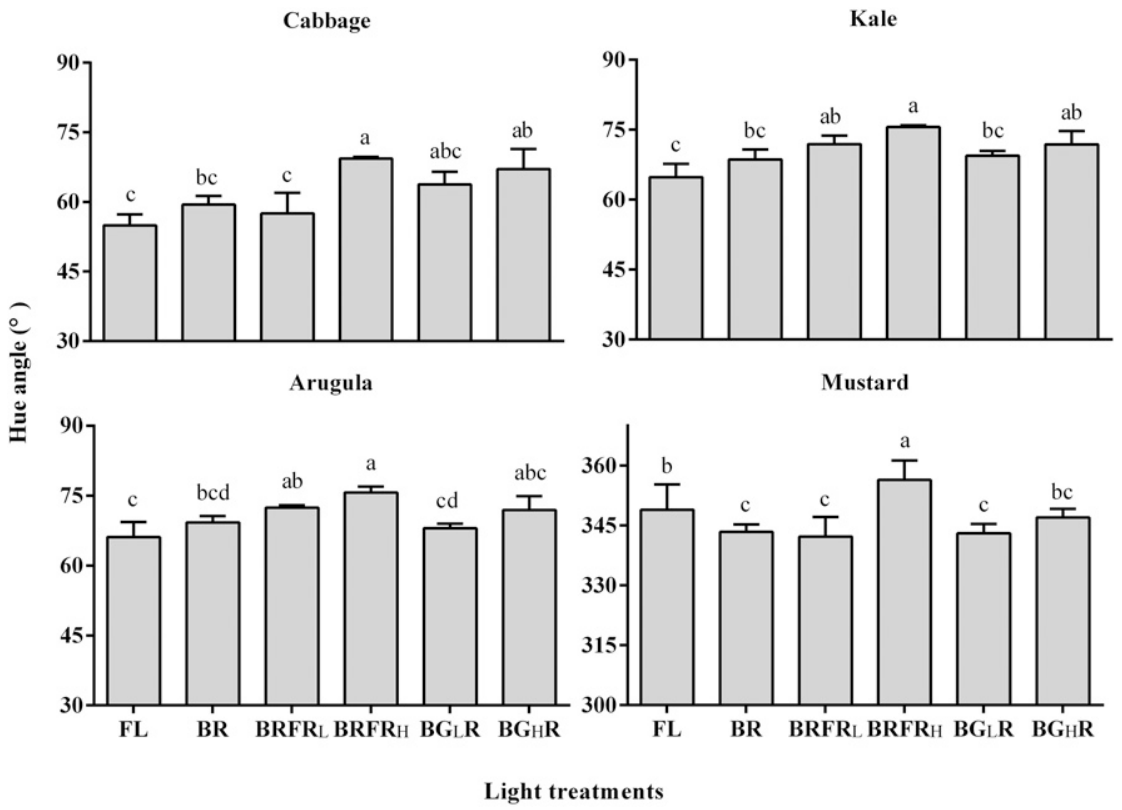

Fig. 2. Hue angle of cotyledon color from four microgreen species grown under different light treatments. Data are the means $\pm \mathrm{SE}(\mathrm{n}=3)$. Bars bearing the same letter are not significantly different at $P \leq 0.05$. $\mathrm{FL}=$ fluorescent light; $\mathrm{BR}=15 \%$ blue and $85 \%$ red; $\mathrm{BRFR}_{\mathrm{L}}=15 \%$ blue and $85 \%$ red with 15.5 $\mu \mathrm{mol} \cdot \mathrm{m}^{-2} \cdot \mathrm{s}^{-1}$ far-red light; $\mathrm{BRFR}_{\mathrm{H}}=15 \%$ blue and $85 \%$ red with additional $155 \mu \mathrm{mol} \cdot \mathrm{m}^{-2} \cdot \mathrm{s}^{-1}$ far-red light; $\mathrm{BG}_{\mathrm{L}} \mathrm{R}=9 \%$ blue, $6 \%$ green, and $85 \%$ red; $\mathrm{BG}_{\mathrm{H}} \mathrm{R}=5 \%$ blue, $10 \%$ green, and $85 \%$ red. The photosynthetic photon flux density of each lighting treatment is $330 \mu \mathrm{mol} \cdot \mathrm{m}^{-2} \cdot \mathrm{s}^{-1}$.

and mustard under $\mathrm{BG}_{\mathrm{H}} \mathrm{R}$ vs. $\mathrm{BRFR}_{\mathrm{H}}$, and for arugula under both $\mathrm{BG}_{\mathrm{H}} \mathrm{R}$ vs. $\mathrm{BRFR}_{\mathrm{H}}$ and $\mathrm{BG}_{\mathrm{L}} \mathrm{R}$ vs. BRFR $\mathrm{L}$.

As shown in Fig. 4, light treatments affected cotyledon area of the tested microgreen species except cabbage. Under BR vs. FL, this trait was increased by $32 \%$ and $23 \%$ for kale and arugula, respectively. Compared with BR, the cotyledon area was increased by $31 \%$ for mustard under $\mathrm{BRFR}_{\mathrm{H}}$ and was reduced by $22 \%$ for kale under $B R F R_{L}$; however, there was no difference among $\mathrm{BR}, \mathrm{BG}_{\mathrm{L}} \mathrm{R}$, and $\mathrm{BG}_{\mathrm{H}} \mathrm{R}$ for all the tested species. Also, cotyledon areas were similar between $\mathrm{BG}_{\mathrm{H}} \mathrm{R}$ and $\mathrm{BRFR}_{\mathrm{H}}$ or between $\mathrm{BG}_{\mathrm{L}} \mathrm{R}$ and $\mathrm{BRFR}_{\mathrm{L}}$ for all the tested species except kale.

Plant biomass. Either fresh biomass or dry biomass was unaffected by the different light treatments for the tested microgreen species (data not shown). The average fresh and dry biomass were 1.60 and $0.13 \mathrm{~kg} \cdot \mathrm{m}^{-2}$ for cabbage, 1.54 and $0.12 \mathrm{~kg} \cdot \mathrm{m}^{-2}$ for kale,
1.48 and $0.14 \mathrm{~kg} \cdot \mathrm{m}^{-2}$ for arugula, and 1.50 and $0.13 \mathrm{~kg} \cdot \mathrm{m}^{-2}$ for mustard.

\section{Discussion}

BR light vs. FL improves appearance quality for some microgreen species without compromising yields. BR, compared with FL, increased the redness of cotyledon color for red-leafed mustard; however, it did not affect cotyledon color for the other three greenleafed species in the present study. The results suggest that red- vs. green-leafed plant species are more sensitive to BR compared with FL. The differences in responses to BR for plants with different leaf color were supported by a previous study on 18 vegetable genotypes in our laboratory (Kong and Zheng, 2019). In that study, red- vs. green-leafed plant genotypes showed higher phenotypic plasticity indices (i.e., higher sensitivity) in response to BR relative to dark. The increase in red coloration is also observed in lettuce leaves under prior-to-harvest supplemental BR (Owen and Lopez, 2015). The increased leaf redness under BR might be due to an increased anthocyanin content, because a significant positive correlation is reported between plant redness and anthocyanin content (Manetas, 2006).

In addition to changing cotyledon color, $\mathrm{BR}$ vs. FL also increased plant height for the tested species except arugula, and increased cotyledon area for arugula and kale. Similar species-specific light responses were reported in previous studies. Chili pepper plants are taller with larger leaves under BR vs. FL, but no difference is found in leaf area of red-leafed lettuce under the same light condition (Johkan et al., 2010). Plant heights of all four tested ornamental species (i.e., petunia, calibrachoa, geranium, and marigold) are increased by BR vs. FL (Mah et al., 2018). The lower B photon flux under BR vs. FL could partly explain the promoted elongation in microgreens in our experiment. Previous studies on tomato and cucumber seedlings indicate that hypocotyl elongation and leaf expansion are inhibited with increased B light photon flux in BR (Nanya et al., 2012; Hernández and Kubota, 2016). Also, FL contains a small proportion of UVA light, which is not present in BR and may also inhibit plant elongation (Kong et al., 2019b).

There was no difference in fresh or dry biomass between BR and FL treatments for all the tested microgreen species in the present study. Similar results are reported on the DW of broccoli microgreens under BR vs. FL (Kopsell et al., 2014). However, BR vs. FL increases fresh biomass in chili pepper leaves and fruits (Gangadhar et al., 2012). The different responses to BR vs. FL treatment between microgreens and chili pepper might have resulted from their different growth periods under lighting treatments. Microgreens were grown for only 11 to $12 \mathrm{~d}$, during which plant photosynthesis and biomass accumulation might be less affected by light spectra than mature plants.

Adding high FR to BR light promotes elongation for some microgreens species and modifies leaf color without affecting yields. With additional high FR added to $\mathrm{BR}$, the cotyledon redness was reduced for red-leafed mustard in the present study. In this case, leaf anthocyanin content might 

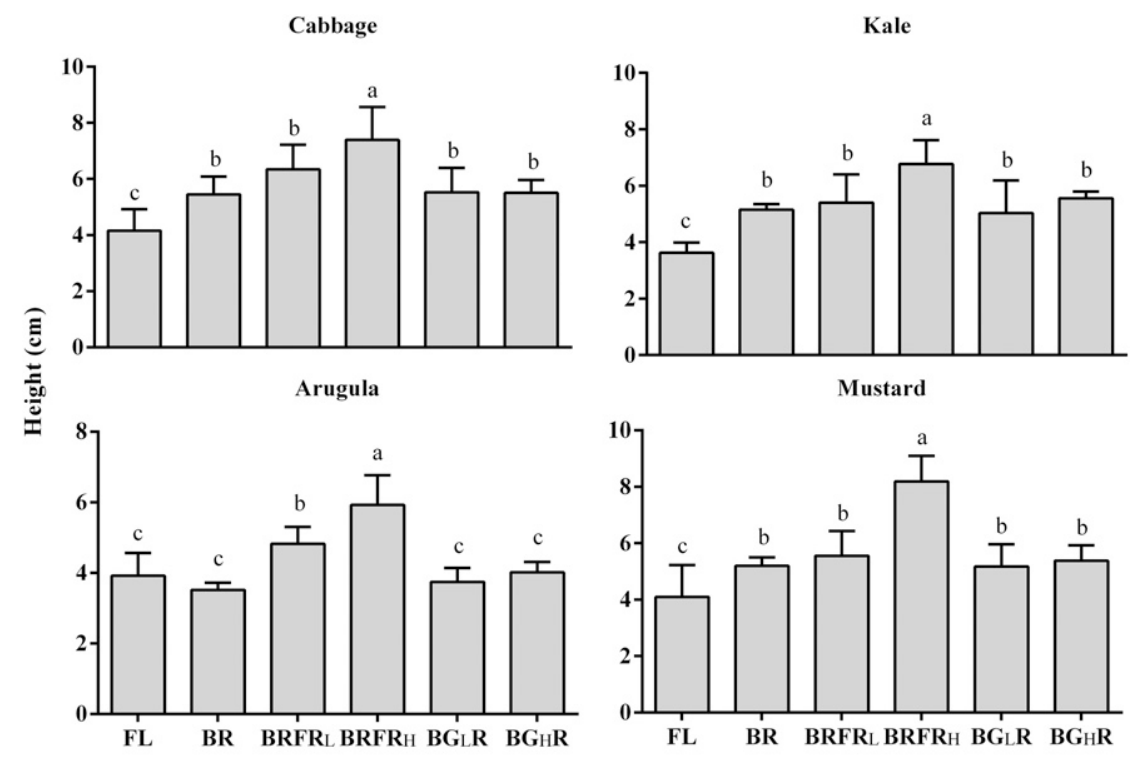

Light treatments

Fig. 3. Individual plant height of four microgreen species grown under different light treatments. Data are the means $\pm \mathrm{SE}(\mathrm{n}=3)$. Bars bearing the same letter are not significantly different at $P \leq 0.05$. FL $=$ fluorescent light; $\mathrm{BR}=15 \%$ blue and $85 \%$ red; $\mathrm{BRFR}_{\mathrm{L}}=15 \%$ blue and $85 \%$ red with $15.5 \mu \mathrm{mol} \cdot \mathrm{m}^{-2} \cdot \mathrm{s}^{-1}$ far-red light; $\mathrm{BRFR}_{\mathrm{H}}=15 \%$ blue and $85 \%$ red with additional $155 \mu \mathrm{mol} \cdot \mathrm{m}^{-2} \cdot \mathrm{s}^{-1}$ far-red light; $\mathrm{BG} \mathrm{L}_{\mathrm{L}} \mathrm{R}=$ $9 \%$ blue, $6 \%$ green and $85 \%$ red; $\mathrm{BG}_{\mathrm{H}} \mathrm{R}=5 \%$ blue, $10 \%$ green, and $85 \%$ red. The photosynthetic photon flux density of each lighting treatment is $330 \mu \mathrm{mol} \cdot \mathrm{m}^{-2} \cdot \mathrm{s}^{-1}$.

have decreased when high FR was added to $\mathrm{BR}$ and resulted in a decreased R:FR ratio, which is also reported in long-stalk starwort (Stellaria longipes) (Alokam et al., 2002). In the present study, the greenness of cotyledons was increased for the green-leafed microgreens (i.e., cabbage, kale, and arugula). This seemed to be contradictory with the common

opinion that increased FR level can reduce leaf chlorophyll content (Demotes-Mainard et al., 2016). However, increased leaf greenness normally resulted from increased relative, rather than absolute, chlorophyll content. In other words, the other pigments, such as anthocyanins and/or carotenoids, might have reduced more than chlorophyll.

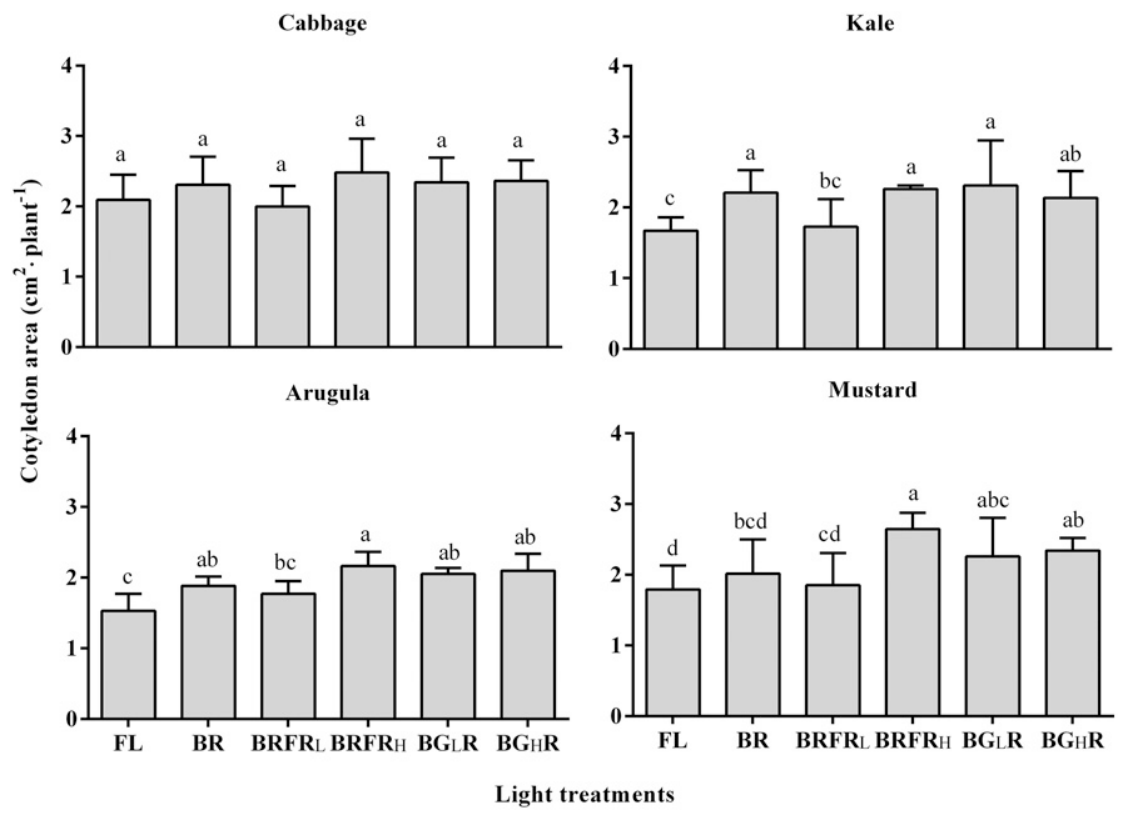

Fig. 4. Cotyledon area of four microgreen species grown under different light treatments. Data are the means \pm SE $(n=3)$. Bars bearing the same letter are not significantly different at $P \leq 0.05$. FL $=$ fluorescent light; $\mathrm{BR}=15 \%$ blue and $85 \%$ red; $\mathrm{BRFR}_{\mathrm{L}}=15 \%$ blue and $85 \%$ red with $15.5 \mu \mathrm{mol} \cdot \mathrm{m}^{-2} \cdot \mathrm{s}^{-1}$ far-red light; $\mathrm{BRFR}_{\mathrm{H}}=15 \%$ blue and $85 \%$ red with additional $155 \mu \mathrm{mol} \cdot \mathrm{m}^{-2} \cdot \mathrm{s}^{-1}$ far-red light; $\mathrm{BG}_{\mathrm{L}} \mathrm{R}=$ $9 \%$ blue, $6 \%$ green, and $85 \%$ red; $\mathrm{BG}_{\mathrm{H}} \mathrm{R}=5 \%$ blue, $10 \%$ green, and $85 \%$ red. The photosynthetic photon flux density of each lighting treatment is $330 \mu \mathrm{mol} \cdot \mathrm{m}^{-2} \cdot \mathrm{s}^{-1}$.
Similarly, increased relative chlorophyll content is reported in kohlrabi microgreens under BRFR relative to BR (Gerovac et al., 2016).

Adding high FR to BR resulted in taller plants of all four microgreen species. This would potentially benefit machine harvesting, which requires a minimum height of 5 cm (Kong et al., 2019a). However, adding low FR did not affect plant height except for arugula. The difference between high and low FR might be due to their reduction on phytochrome activity to different degree. The phytochrome photostationary state (PPS) value, an indicator of phytochrome activity (Sager et al., 1988), was reduced from 0.88 to 0.78 , when high FR was added to BR (Table 2). Normally, plant height increases as a shade-avoidance response with decreasing phytochrome activity (Demotes-Mainard et al., 2016; Hendricks and Borthwick, 1967); however, when low FR was added to BR, the decrease in PPS was too minuscule (from 0.88 to 0.87 ; Table 2) to affect most microgreen species except arugula. This species-specific response was also found on cotyledon area, which was reduced in kale and increased in mustard after adding low and high FR, respectively, to $B R$ in the present study. Similarly, when adding FR to BR, leaf area decreases in geranium and snapdragon, but not in petunia and impatiens (Park and Runkle, 2017).

Although plant height and cotyledon area were increased in some species when high FR was added to $\mathrm{BR}$, the morphological changes did not lead to a significant yield increase. This may be due to the thinner leaves developed under decreased R:FR ratios, as supported by previous studies on bean (Phaseolus vulgaris L.) leaves (Barreiro et al., 1992), and cucumber seedlings (Shibuya et al., 2011). Moreover, the FR LED has had a lower energy efficiency, and a higher price than R or B LED in the past decade (Kubota et al., 2012; Nelson and Bugbee, 2014), which might not be cost-effective for microgreen production currently. However, with the increasing energy efficacy and decreasing price due to the rapid development of LED technology, the potential application of FR LED may become popular in the future (Kusuma et al., 2020).

Combining $G$ with BR light causes no changes in microgreens yield and appearance quality, showing smaller effects than addition of FR. G has a better ability to penetrate plant canopy than R or B, thus BGR (i.e., combining $G$ with $B R$ ) would potentially promote whole-canopy photosynthesis, and benefit plant growth (Kim et al., 2004; Klein, 1992). For example, BGR increases lettuce FW, DW, and leaf area, compared with BR (Son and Oh, 2015); however, in the present study, BGR vs. BR did not change microgreen growth (e.g., biomass). Similar result is also reported in sprouting broccoli (Kopsell et al., 2014). Possibly, for plants without leaves at lower canopy, such as microgreens, combining $\mathrm{G}$ with $\mathrm{BR}$ has little promotion effects on canopy photosynthesis, and thereby plant growth. Nevertheless, 
BGR would benefit growers in checking plant health, because BR produces a purple light that causes plants to look gray/black rather than green (Smith et al., 2017).

Increased $\mathrm{G}$ level in BGR can also induce shade-avoidance response to promote plant growth. For example, in lettuce and kale under a $P P F D$ of $180 \mu \mathrm{mol} \cdot \mathrm{m}^{-2} \cdot \mathrm{s}^{-1}$, when $\mathrm{G}$ proportion in total $P P F D$ increased from $11 \%$ to $22 \%$ (i.e., B decreased from $22 \%$ to $11 \%$ ), leaf expansion and biomass increased accordingly (Meng et al., 2019). However, in the present study, under a PPFD of 330 $\mu \mathrm{mol} \cdot \mathrm{m}^{-2} \cdot \mathrm{s}^{-1}$, when $\mathrm{G}$ percentage increased from $6 \%$ to $10 \%$ (i.e., B decreased from $9 \%$ to $5 \%$ ), no change was found in microgreen growth and appearance quality. Possibly, in the present study, the increase of G percentage was too small to induce shade-avoidance response especially under a higher $P P F D$. As well-known, under the natural vegetative shade, the increased $G$ proportion is normally accompanied by decreased $P P F D$. The effect of greater variation of $\mathrm{G}$ proportions in BGR on microgreens growth and quality needs further studies under a high $P P F D$ of $\approx 300$ to $400 \mu \mathrm{mol} \cdot \mathrm{m}^{-2} \cdot \mathrm{s}^{-1}$.

Although both $G$ and FR can induce shade-avoidance response to promote plant elongation growth, $G$ seems to have less pronounced effects than FR does in a previous study on lettuce and kale (Meng et al., 2019). Similar results were achieved on the plant height of microgreens under BGR vs. BRFR in the present study. Possibly, FR is a more important shade signal than $\mathrm{G}$, because increase of both $\mathrm{G}$ and FR intensity indicates actual shading, whereas the increase of FR intensity also warns potential light competition (Keuskamp et al., 2012).

\section{Conclusions}

In summary, at a PPFD of 300 to 400 $\mu \mathrm{mol} \cdot \mathrm{m}^{-2} \cdot \mathrm{s}^{-1}$, BR vs. FL increased plant height for cabbage, kale, and mustard; enlarged cotyledon area for arugula and kale; and enhanced cotyledon redness for mustard. Adding high-intensity FR $\left(155 \mu \mathrm{mol} \cdot \mathrm{m}^{-2} \cdot \mathrm{s}^{-1}\right)$ to BR further increased plant height for all the species, cotyledon area for mustard, and cotyledon greenness for green-leafed species; however, it reduced cotyledon redness for red-leafed mustard. Substituting G partially for B in BR showed little beneficial effect on crop yield and appearance quality, possibly due to a low proportion of $\mathrm{G}(\leq 10 \%)$ presented. Therefore, BR without G can potentially replace FL as the sole light source for future indoor production of the tested microgreen species under a higher $P P F D$. Although adding FR to BR benefits microgreen growth, the relatively high energy consumption of FR needs to be taken into consideration when growers are optimizing their light spectral quality.

\section{Literature Cited}

Alokam, S., C.C. Chinnappa, and D.M. Reid. 2002. Red/far-red light mediated stem elongation and anthocyanin accumulation in Stellaria long- ipes: Differential response of alpine and prairie ecotypes. Can. J. Bot. 80:72-81.

Barreiro, R., J.J. Guiamét, J. Beltrano, and E.R. Montaldi. 1992. Regulation of the photosynthetic capacity of primary bean leaves by the red: Far-red ratio and photosynthetic photon flux density of incident light. Physiol. Plant. 85:97-101.

Björkman, M., I. Klingen, A.N.E. Birch, A.M. Bones, T.J.A. Bruce, T.J. Johansen, R. Meadow, J. Mølmann, R. Seljåsen, L.E. Smart, and D. Stewart. 2011. Phytochemicals of Brassicaceae in plant protection and human health Influences of climate, environment and agronomic practice. Phytochemistry 72:538-556.

Darko, E., P. Heydarizadeh, B. Schoefs, and M.R Sabzalian. 2014. Photosynthesis under artificial light: The shift in primary and secondary metabolism. Philos. Trans. R. Soc. Lond. B Biol. Sci. 369:20130243.

Davis, P.A. and C. Burns. 2016. Photobiology in protected horticulture. Food Energy Secur. 5:223-238.

Demotes-Mainard, S., T. Péron, A. Corot, J. Bertheloot, J. Le Gourrierec, S. Pelleschi-Travier, L. Crespel, P. Morel, L. Huché-Thélier, R. Boumaza, A. Vian, V. Guérin, N. Leduc, and S. Sakr. 2016. Plant responses to red and far-red lights, applications in horticulture. Environ. Exp. Bot. 121:4-21.

Gangadhar, B.H., R.K. Mishra, G. Pandian, and S.W. Park. 2012. Comparative study of color, pungency, and biochemical composition in chili pepper (Capsicum annuum) under different light-emitting diode treatments. HortScience 47:1729-1735.

Gerovac, J.R., J.K. Craver, J.K. Boldt, and R.G. Lopez. 2016. Light intensity and quality from sole-source light-emitting diodes impact growth, morphology, and nutrient content of Brassica microgreens. HortScience 51:497-503.

Goto, E. 2012. Plant production in a closed plant factory with artificial lighting. Acta Hort. 956:37-49.

Hendricks, S.B. and H.A. Borthwick. 1967. The function of phytochrome in regulation of plant growth. Natl. Acad. Sci. USA 58:2125-2130.

Hernández, R. and C. Kubota. 2016. Physiological responses of cucumber seedlings under different blue and red photon flux ratios using LEDs. Environ. Exp. Bot. 121:66-74.

Johkan, M., K. Shoji, F. Goto, H. Shin-Nosuke, and T. Yoshihara. 2010. Blue light-emitting diode light irradiation of seedlings improves seedling quality and growth after transplanting in red leaf lettuce. HortScience 45:1809-1814.

Jones-Baumgardt, C., D. Llewellyn, Q. Ying, and Y. Zheng. 2019. Intensity of sole-source lightemitting diodes affects growth, yield, and quality of Brassicaceae microgreens. HortScience 54:1168-1174.

Karcher, D.E. and M.D. Richardson. 2003. Quantifying turfgrass color using digital image analysis. Crop Sci. 43:943-951.

Keuskamp, D.H., M.M. Keller, C.L. Ballaré, and R. Pierik. 2012. Blue light regulated shade avoidance. Plant Signal. Behav. 7:514-517.

Kim, H.H., G.D. Goins, R.M. Wheeler, and J.C. Sager. 2004. Green-light supplementation for enhanced lettuce growth under red- and bluelight-emitting diodes. HortScience 39:16171622.

Klein, R.M. 1992. Effects of green light on biological systems. Biol. Rev. Camb. Philos. Soc. 67:199-284.

Kong, Y., D. Kamath, and Y. Zheng. 2019a. Blue versus red light can promote elongation growth independent of photoperiod: A study in four
Brassica microgreens species. HortScience 54:1955-1961.

Kong, Y., K. Schiestel, and Y. Zheng. 2019b. Pure blue light effects on growth and morphology are slightly changed by adding low-level UVA or far-red light: A comparison with red light in four microgreen species. Environ. Exp. Bot. 157:58-68.

Kong, Y. and Y. Zheng. 2019. Variation of phenotypic responses to lighting using combination of red and blue light-emitting diodes versus darkness in seedlings of 18 vegetable genotypes. Can. J. Plant Sci. 99:159-172.

Kopsell, D.A., C.E. Sams, T.C. Barickman, and R.C. Morrow. 2014. Sprouting broccoli accumulate higher concentrations of nutritionally important metabolites under narrow-band light-emitting diode lighting. J. Amer. Soc. Hort. Sci. 139:469-477.

Kubota, C., P. Chia, Z. Yang, and Q. Li. 2012. Applications of far-red light emitting diodes in plant production under controlled environments. Acta Hort. 952:59-66.

Kusuma, P., P.M. Pattison, and B. Bugbee. 2020. From physics to fixtures to food: Current and potential LED efficacy. Hort. Res. 7:56.

Lee, M.J., K.H. Son, and M.M. Oh. 2016. Increase in biomass and bioactive compounds in lettuce under various ratios of red to far-red LED light supplemented with blue LED light. Hort. Environ. Biotechnol. 57:139-147.

Lin, K.H., M.Y. Huang, W.D. Huang, M.H. Hsu, Z.W. Yang, and C.M. Yang. 2013. The effects of red, blue, and white light-emitting diodes on the growth, development, and edible quality of hydroponically grown lettuce (Lactuca sativa L. var. capitata). Scientia Hort. 150:86-91.

Mah, J.J., D. Llewellyn, and Y. Zheng. 2018. Morphology and flowering responses of four bedding plant species to a range of red to far red ratios. HortScience 53:472-478.

Manetas, Y. 2006. Why some leaves are anthocyanic and why most anthocyanic leaves are red? Flora-Morphology, Distrib. Funct. Ecol. Plants 201:163-177.

Massa, G.D., J.C. Emmerich, R.C. Morrow, C.M. Bourget, and C.A. Mitchell. 2006. Plant growth lighting for space life support: A review. Gravit. Space Biol. 19:19-29.

Meng, Q., N. Kelly, and E.S. Runkle. 2019. Substituting green or far-red radiation for blue radiation induces shade avoidance and promotes growth in lettuce and kale. Environ. Exp. Bot. 162:383-391.

Morrow, R.C. 2008. LED lighting in horticulture. HortScience 43:1947-1950.

Nanya, K., Y. Ishigami, S. Hikosaka, and E. Goto. 2012. Effects of blue and red light on stem elongation and flowering of tomato seedlings. Acta Hort. 956:261-266.

Nelson, J.A. and B. Bugbee. 2014. Economic analysis of greenhouse lighting: Light emitting diodes vs. high intensity discharge fixtures. PLoS One 9:e99010.

Owen, W.G. and R.G. Lopez. 2015. End-ofproduction supplemental lighting with red and blue light-emitting diodes (LEDs) influences red pigmentation of four lettuce varieties. HortScience 50:676-684.

Park, Y. and E.S. Runkle. 2017. Far-red radiation promotes growth of seedlings by increasing leaf expansion and whole-plant net assimilation. Environ. Exp. Bot. 136:41-49.

Sager, J.C., W.O. Smith, J.L. Edwards, and K.L. Cyr. 1988. Photosynthetic efficiency and phytochrome photoequilibria determination using spectral data. Trans. ASAE 31:18821889. 
Shibuya, T., K. Itagaki, M. Tojo, R. Endo, and Y. Kitaya. 2011. Fluorescent illumination with high red-to-far-red ratio improves resistance of cucumber seedlings to powdery mildew. HortScience 46:429-431.

Shin, K.S., H.N. Murthy, J.W. Heo, E.J. Hahn, and K.Y. Paek. 2008. The effect of light quality on the growth and development of in vitro cultured Doritaenopsis plants. Acta Physiol. Plant. 30:339-343.

Smith, H.L., L. Mcausland, and E.H. Murchie. 2017. Don't ignore the green light: Exploring diverse roles in plant processes. J. Expt. Bot. 68:2099-2110.
Son, K.H. and M.M. Oh. 2015. Growth, photosynthetic and antioxidant parameters of two lettuce cultivars as affected by red, green, and blue light-emitting diodes. Hort. Environ. Biotechnol. 56:639-653.

Sun, J., J.N. Nishio, and T.C. Vogelmann. 1998. Green light drives $\mathrm{CO}_{2}$ fixation deep within leaves. Plant Cell Physiol. 39:1020-1026.

Treadwell, D.D., R. Hochmuth, L. Landrum, and W. Laughlin. 2016. Microgreens: A new specialty crop. Univ. Florida IFAS Ext. Bul. HS1 164.

Wollaeger, H.M. and E.S. Runkle. 2015. Growth and acclimation of impatiens, salvia, petunia, and tomato seedlings to blue and red light. HortScience 50:522-529.

Xiao, Z., G.E. Lester, Y. Luo, and Q. Wang. 2012. Assessment of vitamin and carotenoid concentrations of emerging food products: Edible microgreens. J. Agr. Food Chem. 60:7644-7651. Ying, Q., Y. Kong, C. Jones-baumgardt, and Y. Zheng. 2020. Responses of yield and appearance quality of four Brassicaceae microgreens to varied blue light proportion in red and blue light-emitting diodes lighting. Scientia Hort. 259:108857. 